\title{
Effects of Four Herbal Plants on Kidney Histomorphology in STZ-induced Diabetic Wistar Rats
}

\author{
Komolafe OA ${ }^{1 *}$, Ofusori DA ${ }^{1}$, Adewole OS ${ }^{1}$, Ajayi SA ${ }^{1}$, ljomone OM${ }^{1}$ and Fakunle $\mathrm{JB}^{2}$
}

${ }^{1}$ Department of Anatomy and Cell Biology, Faculty of Basic Medical Sciences, Obafemi Awolowo University, Ile-Ife, Osun State, Nigeria ${ }^{2}$ Department of Medical Biochemistry, Faculty of Basic Medical Sciences, Obafemi Awolowo University, Ile-Ife, Osun State, Nigeria

\begin{abstract}
The aim of this study is to investigate the effect of four herbal extract and their efficacy on the histomorphometry of the kidney in STZ induced diabetic rats with a view to understanding their antidiabetic properties.

Forty- two healthy adult Wistar rats (Rattus novergicus) with an average weight of $153.4 \mathrm{~g}$ were randomly divided into seven groups $(\mathrm{n}=6)$. STZ $(65 \mathrm{mg} / \mathrm{kg})$ dissolved in citrate buffer was administered intraperitoneally to animals in groups (B-G) while animals in group A received equivalent volume of citrate buffer. Plant extracts $(100 \mathrm{mg} / \mathrm{kg}) \mathrm{were}$ administered daily (orally) to animals in groups C-F and glimepiride (anti-diabetic drug) to animals in group G for fourteen days. After the expiration of the study the animals were sacrificed and the kidneys were excised, fixed in $10 \%$ formol saline for histology and morphometric analysis.

The glomeruli of the diabetic group were atrophied which is validated by significant decrease in its density, shrinkage and increased bowman's space. These observations were also characterized by diminished cellular proliferation, decreased cellular volume and ischemia. The histology and morphometric analysis revealed that the kidney in the group treated with Psidium guajava shows a better histoarchitectural outline of all the four plant extracts used.

This present study therefore suggests that Psidium guajava could be a better alternative therapy in ameliorating diabetic-associated disorders of the kidney.
\end{abstract}

Keywords: Diabetes; Psidium guajava; Veronia amygdalina; Ficus mucuso; Citrullus colocynthis; Kidney

\section{Introduction}

Diabetes mellitus (DM) is a group of metabolic diseases characterized by hyperglycemia (high blood glucose level) which results from defects in insulin secretion, insulin action or both [1]. The chronic hyperglycaemia of DM is associated with long-term damage, dysfunction and failure of various body structures and organs especially the eyes, nerves, heart, blood vessels and also the kidney [1]. Existing therapy for DM are known to provide good glycaemic control, but are believed to do little in regards to the complications to various organs. Besides, these anti diabetic drugs are associated with mild to moderate side effects [2]. In view of this, the present study has investigated the effects of some common plants traditionally used in herbal management of diabetes amongst the Yorubas of Ile-Ife, Nigeria, on the histomorphology of the kidney in STZ-induced Wistar rats.

The herbal plants used for this study were leaves of Veronia amygdalina, shaft of Citrullus colocynthis seed, leaves of Psidium guajava, and leaves of Ficus mucuso (SPP).

Veronia amygdalina (VA) commonly called bitter leaf belongs to the family Asteraceae. It has petiolate leaves of about $6 \mathrm{~mm}$ diameter and elliptic shape. The leaves are green with a characteristic odour and a bitter taste [3]. It is called 'Ewuro' by the Yorubas of Nigeria. The leaves have been used in traditional folk medicine as anthelmintics, antimalarial, antimicrobial anticancer and as a laxative herb [4]. Phytochemical substances in VA include oxalates, phylates and tannins $[5,6]$, and also flavonoids $[7,8]$.

Citrullus colocynthis (CC) popularly known as 'bitter apple', 'colosynth', and 'vine-of-Sodom' is a tropical plant belonging to the family Cucurbitaceae [9]. It is also commonly referred to as 'egusi' amongst the Yorubas of Nigeria. In the traditional medicine, it has been used in treatment of constipation [10], diabetes [11] oedema, fever, jaundice leukaemia, bacterial infections, cancer and used as an abortifacient [12].

Psidium guajava (PG) is a semi deciduous tropical tree commonly known as 'guava' and belongs to the family Myrtaceae. Phytochemical constituent have been shown to include Vitamin C, B1, B2, and B6, free sugars [13]. Guava fruits have been shown to have antioxidant properties [14]. The fruits have been shown to possess hypoglyceamic effects in diabetic mice and human volunteers [13]. Studies have indicated the presence of various flavonoids, terpenoids and their glycosides $[15,16]$, and these compounds have been shown to be antidiabetic $[17,18]$.

Ficus mucuso (FM) belongs to the family Moraceea. The Ficus genus has wide distribution and is used traditionally as medicine, vegetable, food, fodder and fuel wood [19]. Phytochemical analyses of FM have revealed the presence of monoterpenoids and flavonoids [20].

\section{Materials and Methods}

\section{Animal management}

Forty- two healthy adult Wistar rats (Rattus novergicus) with an

*Corresponding author: Komolafe OA, Department of Anatomy and Cell Biology, Faculty of Basic Medical Sciences, Obafemi Awolowo University, IleIfe, Osun State, Nigeria, Tel: +2348034498833; E-mail: bkomolaf@yahoo.com

Received October 30, 2013; Accepted December 26, 2013; Published December 28, 2013

Citation: Komolafe OA, Ofusori DA, Adewole OS, Ajayi SA, ljomone OM, et al. (2013) Effects of Four Herbal Plants on Kidney Histomorphology in STZ-induced Diabetic Wistar Rats. J Cytol Histol 5: 210. doi:10.4172/2157-7099.1000210

Copyright: (c) 2013 Komolafe OA, et al. This is an open-access article distributed under the terms of the Creative Commons Attribution License, which permits unrestricted use, distribution, and reproduction in any medium, provided the original author and source are credited. 
average weight of $153.4 \mathrm{~g}$ were procured from the animal house of College of Health Sciences, Obafemi Awolowo University, Ile - Ife, Osun State. The animals were kept under standard laboratory condition of good lighting, moderate temperature, and adequate ventilation in a hygienic environment. They were feed on standard rat chow containing proteins, carbohydrate, fats, vitamins and minerals. The animals were placed under standard laboratory protocols as stipulated by the Institutional Animal Care and Use Committee (IACUC, 2010).

\section{Animal grouping and treatment}

The animals were randomly divided into seven groups of 6 animals each

- Group A - control normal rats administered with equivalent volume of citrate buffer.

- Group B - experimentally-induced diabetic rats were administered with single intraperitoneal injection of streptozotocin $(65 \mathrm{mg} / \mathrm{kg})$,

- Group C - experimentally-induced diabetic rats $(65 \mathrm{mg} / \mathrm{kg})$ treated with aqueous extract of VA leaves $(100 \mathrm{mg} / \mathrm{kg})$ orally, dissolved in normal saline for 14 days,

- Group D - experimentally-induced diabetic rats $(65 \mathrm{mg} / \mathrm{kg})$ treated with aqueous extract of shaft of CC seeds $(100 \mathrm{mg} / \mathrm{kg})$ orally, dissolved in normal saline for 14 days,

- Group E - experimentally-induced diabetic rats $(65 \mathrm{mg} / \mathrm{kg})$ treated with aqueous extract of PG $(100 \mathrm{mg} / \mathrm{kg})$ orally, dissolved in normal saline for 14 days,

- Group F - experimentally-induced diabetic rats $(65 \mathrm{mg} /$ $\mathrm{kg})$ treated with aqueous extract of FM $(100 \mathrm{mg} / \mathrm{kg})$ orally, dissolved in normal saline for 14 days,

- Group G - experimentally-induced diabetic rats $(65 \mathrm{mg} /$ $\mathrm{kg})$ treated with a standard antidiabetic drug $(2 \mathrm{mg} / \mathrm{kg}$ of glimepiride) orally, dissolved in normal saline for 14 days.

\section{Plants materials}

Preparation of extracts: The plant leaves were procured from a local market in Ile-Ife metropolis in Osun state, Nigeria. The leaves were taken to the herbarium in the Department of Botany, Obafemi Awolowo University, Nigeria, to confirm identification. The leaves and shaft of the plants were air dried and powdered in a warring blender. The extraction process of the plant leaves of VA (425 g), PG (970 g), FM (370 g) and shaft of CC (615 g) were prepared by dissolving it in $2.9 \mathrm{~L}, 3.19 \mathrm{~L}, 3.5 \mathrm{~L}$ and $2.2 \mathrm{~L}$ respectively for $72 \mathrm{hr}$ with intermittent shaking. Thereafter, the solution was filtered using a filter paper. The filtrate was then concentrated in vacuo at $35^{\circ} \mathrm{C}$ using a rotator vacuum evaporator (Buchi Rotavapor, R110 Schweiz). The extracts were oven dried at $37^{\circ} \mathrm{C}$, and the respective percentage yield $(3.00 \mathrm{~g}, 2.65 \mathrm{~g}, 5.34 \mathrm{~g}$ and $1.76 \mathrm{~g}$ ) were stored until ready to use. The aliquot portion of each of the extracts were weighed and dissolved in normal saline for use on each day of the experiment.

\section{Induction of diabetes}

Diabetes mellitus was experimentally-induced in groups B, C, D, E, F, and G by a single intraperitoneal injection of $65 \mathrm{mg} / \mathrm{kg}$ body weight of streptozotocin (Tocris Bioscience, UK) dissolved in $0.1 \mathrm{M}$ sodium citrate buffer (pH 6.3) [21]. Diabetes was confirmed in animals 48 hours after induction, by determining fasting blood glucose level using a digital glucometer (Accu-chek Advantage, Roche Diagnostic, Germany) consisting of a digital meter and the test strips using blood samples obtained from the tail vein of the rats. The animals were stabilized for twenty eight days before the commencement of extract and glimepiride administration. The fasting blood glucose was subsequently monitored throughout the experimental period. Animals in group A were given equal volume of citrate buffer used in dissolving streptozotocin intraperitoneally.

\section{Method of administration of extracts}

The animals were fed orally using orogastric tube. The animals were held with a glove with the left hand such that the neck region was held by the fingers to still the neck while being fed. Treatment was done at 07.00 hour every day before the animals were fed over a period of two weeks (14 days).

\section{Sacrifice and specimen collection}

The animals were sacrificed by cervical dislocation 24 hours after the expiration of research. The kidneys were excised following midlineabdominal incision. The kidney which is reddish-brown organ situated posteriorly behind the peritoneum on each side of the vertebral column were excised and weighed.

\section{Histological evaluation}

The harvested kidneys were fixed in $10 \%$ formal saline for a minimum of 48 hours and process routinely for paraffin embedding. Serial sections were obtained at $5 \mu \mathrm{m}$ from a rotary microtome (Bright B5040, Huntington England) and stained using routine haematoxylin and eosin method. Stained sections were viewed under a LEICA digital microscope (DM 750) and photomicropgraphs were taken with the aid of an attached camera (Leica ICC50).

\section{Histomorphometric analysis}

The stained sections were subjected to morphometric analysis recommended by World

Health Organization W.H.O. [22]. which included: dividing the eye piece occulometer into two 100 small divisions, the stage micrometer scale was made up to $1 \mathrm{~mm}$ divided into $0.1 \mathrm{~mm}$ divisions and each 0.1 $\mathrm{mm}$ was divided into $0.01 \mathrm{~mm}$, the eye piece scale (occulometer) was inserted into the eye piece of the microscope by removing the superior lens thus placing the scale on the field stop, the stage micrometer was also placed on the stage of the microscope, the stage scale was focused by the low power objective lens ( $\mathrm{x} 4)$, the stage and the eye piece scales were adjusted until there was a parallel point between the two scales, the number of the eye piece divisions and its corresponding stage measurements was noted; (if 70 occulometer divisions equal to $14 \mu \mathrm{m}$, all the objective lens were thus calibrated). Calibration was needed for each microscope use. The occulometer fixed into the Olympus Microscope was then focused through stained sections of the tissue to allow for the measurement of the parameters.

\section{Statistical analysis}

Data were expressed as mean \pm SEM. Data were analysed using One-way ANOVA, followed by Student Newman-Keuls (SNK) test for multiple comparisons. Significant difference was taken as $\mathrm{p}<0.05$.

\section{Results}

\section{Effects of extracts on relative weight of kidney}

As shown in Table 1, the relative weights of the kidney was significantly reduced in all groups (B-G) compared to control group (A). 
Citation: Komolafe OA, Ofusori DA, Adewole OS, Ajayi SA, ljomone OM, et al. (2013) Effects of Four Herbal Plants on Kidney Histomorphology in STZ-induced Diabetic Wistar Rats. J Cytol Histol 5: 210. doi:10.4172/2157-7099.1000210

Page 3 of 5

\section{Effects of extracts on kidney histology}

As shown in Figure 1, Control animals showed normal kidney histology. The glomeruli were well demonstrated with normal bowman space. The renal tubules filling the bulk of the kidney parenchyma were clearly observed. Diabetic kidney, in Group $\mathrm{B}$, showed atrophy of the glomeruli and the tubules were fairly

\begin{tabular}{|l|c|c|}
\hline Groups & Absolute weight of kidney (g) & Relative weight of kidney (\%) \\
\hline A: Control & $1.05 \pm 0.09^{\mathrm{a}}$ & $1.07 \pm 0.05^{\mathrm{d}}$ \\
\hline B: Diabetic & $1.14 \pm 0.04^{\mathrm{a}}$ & $0.85 \pm 0.05^{\mathrm{bc}}$ \\
\hline C: Diabetic+VA extract & $1.69 \pm 0.08^{\mathrm{c}}$ & $0.73 \pm 0.02^{\mathrm{ab}}$ \\
\hline D: Diabetic+CC extract & $1.65 \pm 0.05^{\mathrm{c}}$ & $0.70 \pm 0.03^{\mathrm{a}}$ \\
\hline E: Diabetic+PG extract & $1.40 \pm 0.11^{\mathrm{b}}$ & $0.82 \pm 0.02^{\mathrm{abc}}$ \\
\hline F: Diabetic+FM extract & $1.70 \pm 0.09^{\mathrm{c}}$ & $0.78 \pm 0.04^{\mathrm{abc}}$ \\
\hline G: Diabetic+Glimepiride & $1.65 \pm 0.05^{\mathrm{c}}$ & $0.72 \pm 0.02^{\mathrm{a}}$ \\
\hline
\end{tabular}

Values are given as Mean \pm SEM in each group.

$a, b, c, d, a b, b c, c d$, abc within column signifies that means with different letters differs significantly at $p<0.05$ while means with the same letters does not differ significantly at $p<0.05$ (using one way ANOVA with SNK).

Table 1: Absolute/relative weights of the kidney.
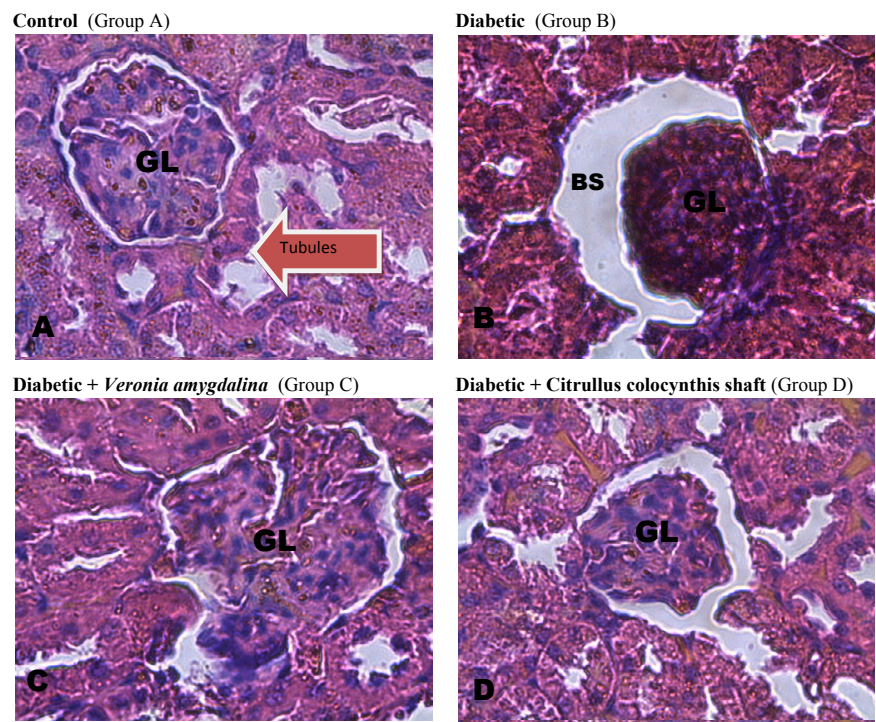

Diabetic + Citrullus colocynthis shaft (Group D)
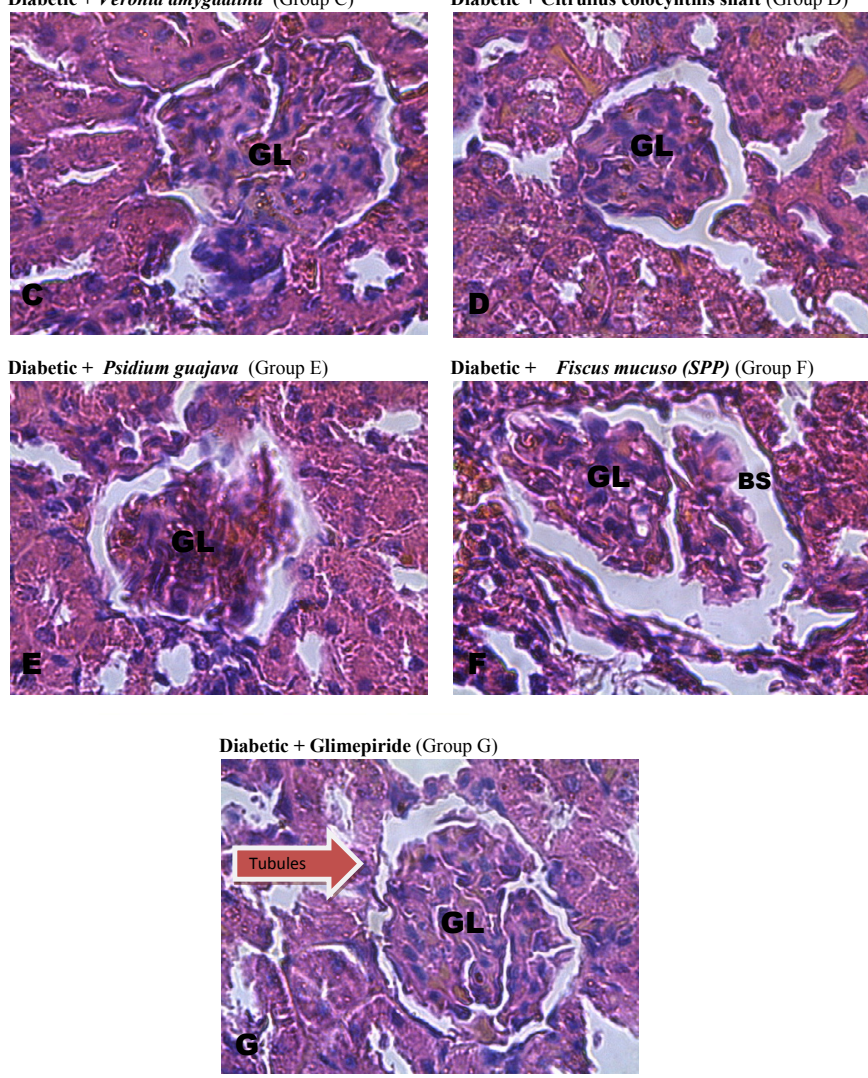

Figure 1: Photomicrographs of kidney of Groups A, B, C, D, E, F, and G. (H\&E x400). GL: glomerulus. There was atrophy of the glomerulus and the tubules are fairly preserved in the diabetic animals (Figure 1B). The extract treated groups (Figures 1C-1F) reveals renal tissue regenerations which shows a remarkable reversible cellular injury as compared with group $B$. 


\begin{tabular}{|c|c|}
\hline Groups & Glomerular density (glomeruli/mm $\mathbf{m}^{\mathbf{}}$ ) \\
\hline A: Control & $17.60 \pm 1.21^{\mathrm{a}}$ \\
\hline B: Diabetic & $9.80 \pm 1.36^{\mathrm{b}}$ \\
\hline C: Diabetic+VA extract & $13.20 \pm 1.36^{\mathrm{b}}$ \\
\hline D: Diabetic+CC extract & $21.40 \pm 1.03^{\mathrm{a}}$ \\
\hline E: Diabetic+PG extract & $24.60 \pm 1.47^{\mathrm{ac}}$ \\
\hline F: Diabetic+FM extract & $18.80 \pm 1.46^{\mathrm{a}}$ \\
\hline G: Diabetic+Glimepiride & $20.00 \pm 1.58^{\mathrm{a}}$ \\
\hline
\end{tabular}

Values are given as Mean \pm SEM in each group.

$a, b$, ac within row signifies that means with different letters differs significantly at $p<0.05$ while means with the same letters does not differ significantly at $p<0.05$ (using one way ANOVA with SNK).

Table 2: Glomerular density.

preserved. Administration of the extracts and antidiabetic drug improves cellular regeneration which is quite prominent in Groups $\mathrm{C}$ and $\mathrm{G}$.

\section{Effects of extracts on histomorphometric glomerular density}

As shown in Table 2, there was significant decrease $(p<0.05)$ in glomerular density of diabetic animals (Group B) compared to control, extracts (Groups D, E, F) and drug treated groups. Group C (treated with VA extract) showed no significant improvement $(\mathrm{p}<0.05)$ in glomerular density while group $\mathrm{E}$ showed significant increase in density compared to control.

\section{Discussion}

Long-term damage, dysfunction and failure of the kidneys are a major complication of diabetes mellitus [1]. Disorders of the kidneys are serious secondary consequence of diabetes, resulting in end stagerenal diseases. Increased glucose levels in the blood have been shown to lead to oxidative stress, which is considered as one of the causative factor for diabetes-associated kidney disorders [23]. STZ-induced diabetic rodents are seen to develop kidney disorders similar to the early stage of human diabetic-associated disorders of the kidney [24]. Renal hypertrophy has been reported in diabetes [23].

Also diabetic nephropathy has been known to cause renal failure thus leading to mortality and morbidity.

However the histological and histomorphometric evaluation of the present study shows atrophy rather than hypertrophy in the glomeruli of diabetic animals which is validated by significant decrease in its density and shrinkage. These observations were also characterized by diminished cellular proliferation, decreased cellular volume and ischemia.

The primary function of the glomeruli is to assist in the production of ultrafiltrate of the plasma such as $\mathrm{Na}^{+}$, water and urea for further processing by the renal tubules thus playing a vital role in the maintenance of fluid and electrolyte homeostasis.

Administration of the extracts improves the histoarchitecture of the kidney and by extension restores its functionality. The groups administered with PG extract demonstrated a distinct regenerative capacity over the other three extract. This was closely followed by the group administered with FM extract.

Previous studies have reported some similar histopathological findings $[24,25]$. The plant extracts used for the study, are common herbal plant used traditionally in the management of diabetes, amongst the Yorubas of Ile-Ife, Nigeria. Three of these plants - VA, CC, and PG; have been reported to possess anti-diabetic properties $[3,9,13]$. The four medicinal plants used in this study are well known for their antioxidant properties which are due to their high level content of flavonoids $[7,8,11,15,20]$. The present study has provided useful information in the management of kidney related disorders resulting from diabetes.

\section{References}

1. Gavin JR, Alberti KGMM, Davidson MB, Defronzo RA, Drash A, et al. (2003) Report of the Expert Committee on the Diagnosis and Classification of Diabetes Mellitus. Diabetes care 26: S5-S20.

2. Grundy SM, Benjamin IJ, Burke GL, Chait A, Eckel RH, et al. (1999) Diabetes and cardiovascular disease: a statement for healthcare professionals from the American Heart Association. Circulation 100: 1134-1146.

3. Akpaso MI, Atangwho IJ, Akpantah A, Fischer VA, Igiri AO, et al. (2011) Effect of Combined Leaf Extracts of Vernonia amygdalina (Bitter Leaf) and Gongronema latifolium (Utazi) on the Pancreatic ß-Cells of Streptozotocin-Induced Diabetic Rats. British J Medicine \& Medical Res 1: 24-34.

4. AKAH, A, ALEMJI, JA, SALAWU, OA, OKOYE, TC, OFFIAH, NV, Effects of Vernonia amygdalina on Biochemical and Hematological Parameters in Diabetic Rats. Asian J Medical Sci 2009 1: 108-113.

5. Eleyinmi AF, Sporns P, Bressler DC (2008) Nutritional compostion of Gongronema latifolium and Vernonia amygdalina. Nutri \& Food Sci 38: 99-100.

6. Ejoh RA, Nkonga DV, Innocent G, Moses C (2007) Nutritional components of some nonconventional leafy vegetables consumed in Cameroon. Pak J of Nutr 6: 712-6717.

7. Udens I EA, ljeh II, Ogbonna U (2002) Effect of traditional processing on the phytochemical and nutrient composition of some local Nigerian leafy vegetables. J Sci Tech 8: 37-40

8. Tona L, Cimanga RK, Mesia K, Musuamba CT, De Bruyne T, et al. (2004) In Vitro Antiplasmodial activity of extracts and fractions of seven medicinal plants used in the Democratic Republic of Congo. Journal of Ethnophamacology. 93 27-32.

9. Dallak M, Bin-Jaliah I (2010) Antioxidant activity of Citrullus colocynthis pulp Extract in the RBC's of alloxan-induced diabetic rats. Pak J Physiol 6: 1-5.

10. Alkofahi A, Batshoun R, Owis W, Najib N (1996) Biological activity of some Jordanian plants extracts. Fitoterapia $435-442$

11. Ziyyat A, Legssyer A, Mekhfi H, Dassouli A, Serhrouchni M, et al. (1997) Phytotherapy of hypertension and diabetes in oriental Morocco. J Ethnopharmacol 58: 45-54.

12. Madari H, Jacobs RS (2004) An analysis of cytotoxic botanical formulations used in the traditional medicine of ancient Persia as abortifacients. J Nat Prod 67: 1204-1210.

13. Rai PK, Jaiswal D, Mehta S, Watal G (2009) Anti-hyperglycaemic potential of Psidium guajava raw fruit peel. Indian J Med Res 129: 561-565.

14. Jiménez-Escrig A, Rincón M, Pulido R, Saura-Calixto F (2001) Guava fruit (Psidium guajava L.) as a new source of antioxidant dietary fiber. J Agric Food Chem 49: 5489-5493.

15. Ahamad FB, Holdsworth DK (2003) Medicinal plants of Sabah, East Malaysia Part I. Pharm Biol 41: 340-346.

16. Huang KC (1998) Pharmacology of Chinese herbs. CRC Press: Boca Raton USA.

17. Vetrichelvan T, Jegadeesan M (2002) Anti-diabetic activity of alcoholic extract of Aerva lanata (L.) Juss. ex Schultes in rats. J Ethnopharmacol 80: 103-107.

18. Andrade-Cetto A, Wiedenfeld H (2001) Hypoglycemic effect of Cecropia obtusifolia on streptozotocin diabetic rats. J Ethnopharmacol 78: 145-149.

19. Gojayev AS, Bankeu JK, Guliyev AA, Tsamo E, Choudhary MJ (2011) Xanthine oxidase inhibitory activity of natural Compounds from Ficus mucuso (moraceae). UOT 581.19: 577.161

20. Ahoua ARC, Kone MW, Konan A, Tra BH, Bonfoh B, (2012) Antioxidant activity of eight plants consumed by great apes in Côte d'Ivoire. Afr J Biotech 11: 11732-11740.

21. Topal G, Koç E, Karaca C, Altuğ T, Ergin B, et al. (2013) Effects of Crataegus microphylla on vascular dysfunction in streptozotocin-induced diabetic rats. Phytother Res 27: 330-337. 
Citation: Komolafe OA, Ofusori DA, Adewole OS, Ajayi SA, ljomone OM, et al. (2013) Effects of Four Herbal Plants on Kidney Histomorphology in STZ-induced Diabetic Wistar Rats. J Cytol Histol 5: 210. doi:10.4172/2157-7099.1000210

Page 5 of 5

22. World Health Organization (1991) Calibrating the microscope. In: Basic laboratory methods in medical parasitology.

23. Kiran G, Nandini CD, Ramesh HP, Salimath PV (2012) Progression of early phase diabetic nephropathy in streptozotocin-induced diabetic rats: evaluation of various kidney-related parameters. Indian J Exp Biol 50: 133-140.
24. Teoh SL, Abd Latiff A, Das S (2010) Histological changes in the kidneys of experimental diabetic rats fed with Momordica charantia (bitter gourd) extract. Rom J Morphol Embryol 51: 91-95.

25. Zafar M, Naqvi NS, Ahmed M, Kaimkhani ZA (2009) Altered kidney morphology and enzymes in streptozotocin-induced diabetic rats. Int. J. Morphol 27: 783790 . 